\title{
Organic Agroedu-Tourism Attractions toward an Interesting Outdoor Environmental Education to Junior High School Students
}

\author{
Ayu Raisa Khairun Nisa' ${ }^{* 1}$, Setijono Samino ${ }^{1}$, Endang Arisoesilaningsih ${ }^{1}$ \\ ${ }^{1}$ Biology Department, Faculty of Mathematics and Natural Sciences, Brawijaya University, Indonesia
}

\section{ABSTRACT}

The purpose of this study is to evaluate two organic agroedu-tourism attractions developed to 42 students of eight graders of three junior high schools in the village and one school in the city. Organic agroedu-tourism offers two tour programs namely Organic Garden Tour and Organic Farming Technology. Appreciations of the participants were determined by pre and post test after joining the organic agroedu-tourism. The data were analyzed by using descriptive statistics. This study shows that $78.6 \%$ of the participants prefer the Organic Garden Tour and 21.4\% find that the Organic Farming Technology is better. Organic agroedu-tourism can develop cognitive aspect of participants from score 1 turned into 3. Most participants had a high interest in joining the organic egroedu-tourism. Organic agroedu-tourism is also able to meet the expectations of participants that are indicated by an increase in the skills and experience of participants from score 2 to 5. Satisfaction of the participants can also be assessed from the high appreciation average before and after joining Organic agroedu-tourism, which are score 4 . The appreciation of the participant is shown by their willingness to invite other people to join. Factors affecting participants' satisfaction were family background, socio-economy background, personal perception and knowledge. Based on the result, organic agroedu-tourism shows strength to develop the participants' understanding, knowledge and skills in integrated organic farming system, even though not all participants are interested to join all programs provided. Farmer groups need to improve the quality of organic agroedu-tourism, for example, completing the facilities and agreed on tourism attractions, enhancing farmers' skills as tour guide, providing organic agroedu-tourism program relevant to the school curriculum, and promoting it to public.

Keywords: agroedu-tourism, appreciation, junior high school students, organic farming

\section{INTRODUCTION}

The vision of Indonesia Agriculture 2025 is developing sustainable agriculture to improve food security and farmers' welfare [1]. One way to achieve this vision is by promoting home gardening. According to [2], around 10 million hectares of potential yards in Indonesia are not optimally managed. The condition is an opportunity if the landowner wants to implement a home gardening as the old tradition. Home gar-

\footnotetext{
"Corresponding author:

Ayu Raisa Khairun Nisa'

Biology Department, Brawijaya University, Malang

65145, Indonesia

E-mail: chabio29@gmail.com
}

-dening is an effort to use arable land to conserve food crops, to provide medical herbs, to conserve food crops, to provide medical herbs, food and nutrition, and to increase the society's income and welfare. Home gardening also increases social interactions, reduces stress, increases the love of nature [3], and creates comfort and a healthier environment. This activity also contributes in education, especially in environmental education [4].

Home gardening could be farmers' ecoentrepreneurship activities since the business activities are integrated with environmental preservation [5]. Eco-entrepreneurship provides eco-friendly products and services $[6,7]$, such as reducing pollution, but it is still producing sustainable profits [8]. 
One of the eco-entrepreneurship activities is agroedu-tourism that combines an agricultural tour and education. Attractions that are offered can be information and integrated organic farm products. Agroedu-tourism provides opportunities for farmers to earn profits and simplify the agricultural marketing chain. The activities can empower and optimize the utilization of land as the center of education, research, and recreation.

Karya Makmur 1 Farmer Group in Malang regency developed home gardens as an integrated organic farming and now it is starting to conduct eco-entrepreneurship through organic agroedutourism. So far, the visitors are students, other farmers groups and government agencies. Junior high school students are the main target in this research. Studies on student interest showed that younger generations had low desirability to enroll in agricultural vocational school in Demak, Central Java [9]. Census of Agriculture [10] noted that there was shrinkage of 5.04 million farm families from 31.17 million families per year in 2003 to 26.13 million families annually in 2013. This information indicates that people are not interested in becoming a farmer as these sectors provide low income and social status. Being a farmer is the last alternative when education graduates are not welcome in the world of work. This condition is contradiction with Indonesia, which is known as an agricultural country. The organic farming becomes a profitable business opportunity, therefore trade of organic products in the world reached 63 billion USD in 2011 and increased by 25\% since 2008.
The demand of organic products is higher as increasing public awareness for healthy living [11, 12].

Therefore, in order to improve the service of farmer group, it is necessary to study the efficiency of organic agroedu-tourism on junior high school students because the attraction and tour packages offer agricultural education. So, through organic agroedu-tourism it is expected that student will not only enjoy travelling but they will also get motivation and information about the opportunities to be agriculture entrepreneurs.

\section{MATERIALS AND METHODS}

This research was carried out on September 2012 until November 2013. It was conducted in the area of Karya Makmur 1 Farmer Group, Wonorejo Village, Malang (07\%48'49.4'S and $\left.112^{\circ} 39^{\prime} 32.9^{\prime \prime} \mathrm{N}\right)$. The distance of this location is only 4 miles from Lawang-Surabaya highway and it is one of corridors to Wonosari Tea Plantation. The water supply which decreases in the dry season can reduce the production of organic vegetables.

The profile of the success organic farming practices known by using qualitative descriptive method. Participants involved in the organic agroedu-tourism experiments were around 42 students that consist of 32 students from three village junior high schools and 10 students from one city junior high school (Table 1).

Table 1. Participant profile of organic agro-edutourism

\begin{tabular}{|c|c|c|c|c|c|}
\hline No. & $\begin{array}{l}\text { Schools } \\
\text { code }\end{array}$ & Region & Distance* & Parental occupational background & Sum $(n)$ \\
\hline 1. & V1 & Village & $16 \mathrm{~km}$ & $\begin{array}{l}\text { Entrepreneur }(50 \%) \text {, farmer }(20 \%) \text {, private } \\
\text { employees }(20 \%) \text {, soldier }(10 \%) \text {. }\end{array}$ & 10 \\
\hline 2. & $\mathrm{~V} 2$ & Village & $8 \mathrm{~km}$ & $\begin{array}{l}\text { Entrepreneur }(30 \%) \text {, private employees }(30 \%) \text {, } \\
\text { soldier }(20 \%) \text {, farmer }(10 \%) \text {, driver }(10 \%)\end{array}$ & 10 \\
\hline 3. & V3 & Village & $3 \mathrm{~km}$ & $\begin{array}{l}\text { Farmer }(50 \%) \text {, entrepreneur }(33 \%) \text {, private } \\
\text { employees }(17 \%)\end{array}$ & 12 \\
\hline 4. & $\mathrm{C} 1$ & City & $26 \mathrm{~km}$ & $\begin{array}{l}\text { Private employees }(70 \%) \text {, civil servants }(20 \%) \text {, } \\
\text { entrepreneur }(10 \%)\end{array}$ & 10 \\
\hline
\end{tabular}

${ }^{*}$ Distance between school and ecotourism site

The participants were asked to fill out a questionnaire before joining the organic agroedutourism. Question materials of the questionnaire include four aspects of cognitive, preferences, expectations and appreciation. Organic agroedu- tourism provides two packages namely Organic Garden Tour and Organic Farming Technology with the duration of 90 minutes on each package. Organic Garden Tour provides some activities like walking around the village, visiting goat farm 
to feed and to take pictures with them, and visiting an organic fruit and vegetable garden (Figure 1a-d). Organic Farming Technology provides some activities like milking goats, making compost and liquid fertilizers, and making organic vegetable planting media (Figure 1e-h). All participants joined both agroedutourism packages and enjoyed freshly harvested organic cuisine. Afterall, participants were asked to fill out a questionnaire after joining the whole activities. The accumulated data were tabulated in Microsoft Excel and analyzed descriptively.

\section{RESULTS AND DISCUSSION}

\section{a. Organic Agroedu-tourism activity}

The participants were enthusiastic to join organic agroedu-tourism (Figure 1) because they have a chance of learning outside the classroom and travelling all at once. Previous studies reported that agroedu-tourism of organic rice to elementary school students also showed that activities held in rice field were more exciting rather than those in the school yard or classroom [13].
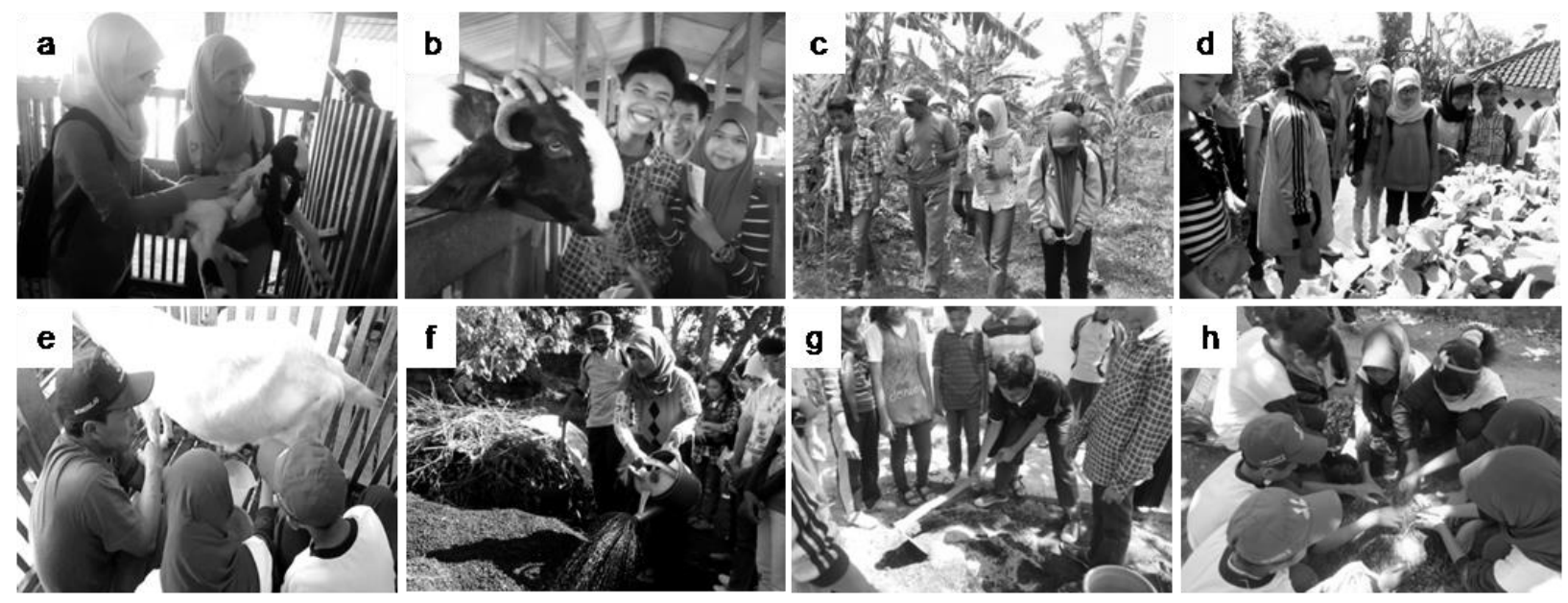

Figure 1. Organic agroedu-tourism provided by Karya Makmur 1 Farmer Group. a-d) Organic Garden Tour; e-h) Organic Farming Technology Tour. a) Attraction of photos with livestock; b) Attraction of feeding goats; c) Walking around an organic banana garden; d) Visiting an organic vegetable garden; e) Milking goats; f)Making compost; g) Making organic vegetable media; h) Planting organic vegetable.

Organic agroedu-tourism is suitable for outdoor environmental education because the program helps the students to remember and understand the benefits of waste processing, home gardening and healthy food consuming. This activity enables participants to feel and to combine theory and real condition, so it will be surely more memorable and embedded in their memories. Similar result showed that outdoor education proved positive influences for candidate of elementary school teachers to increase their understanding on environmental conservation concept [14]. Field trips provide many advantages in helping participants to develop individual or team psychomotor skill and to understand subjects of environmental education [15]. This approach invites students to be aware of the role of humans in nature that can develop their understanding about the correct behavior on the environment holistically.

\section{b. The most exciting packages of organic agroedu-tourism}

The most interesting organic agroedu-tourism package is the Organic Garden Tour shown by $78.6 \%$ of the participant who preferred this package after joining all activities (Figure 2). This package presents activities like walking around the village to see the farmer's life, interacting with animals, introducing a kind of vegetables and fruit and then stimulating participants to imagine the potential of applying integrated farming at home. Those activities and the package name 'Organic Garden Tour' seemed to have attracted the participants to choose this package. Some 
children's characteristics are explorative and adventurous [16]. Children have strong willingness and curiosity so they are more interested to try, to explore and to learn new things. In addition, one of the alternative learning models is the outdoor education school that contains challenging activities, educative and students become closer with nature.

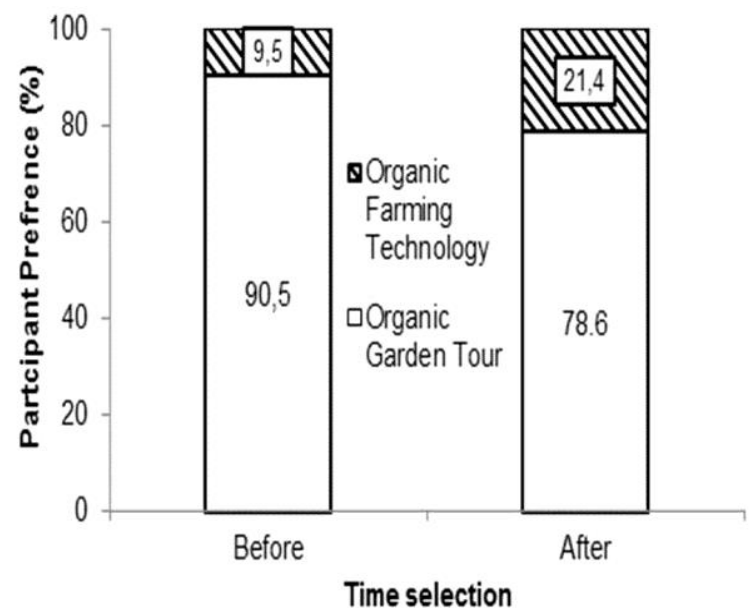

Figure 2. The preference of participants about organic agroedu-tourism packages before and after participating.

Although most participants like Organic Garden Tour, farmer groups need to add attractions and provide more interesting innovation in this package because some participants change their choice after joining the full package of organic agroedu-tourism. Participants who liked Organic Farming Technology were only $9.5 \%$ in the beginning and increased to $21.4 \%$ after joining the agroedu-tourism organic. The participants changed their minds about Organic Farming Technology because it provides more attractive attractions, and it provides opportunities to students to try various experiences in agriculture field.

The low interest of participants in choosing Organic Farming Technology could be influenced by their perception about the content of the activity. They thought that the activity tended to be a lecture or explanation about agricultural theories. A study reported that students tend to be bored to attend a course held by teacher learning center [17]. Besides, other factors that affect the product selection by customer are needs, perceptions, attitudes and personal characteristics of the individual [18]. The condition suggests that the early perceptions and interests of the consumer greatly affect the tour package selection decisions.

The number of $11.9 \%$ of participants changed their choice of tour packages at the end of the activity. Changes in the interest may be affected by the differences in understanding between the activities offered and acquired as well as the many benefits derived after comparing all the packages that followed. Participants might change their interest and expectations because of tourism products are not able to provide their satisfaction [19]. The phenomenon suggested that a tourist attraction have decreases in innovation, maintenance and development of tourism objects. Based on the analysis of variation in activity, Organic Farming Technology has a chance of developed from organic agroedu-tourism. One way to improve the understanding of participants for this package is by changing the named package with a more interesting and fun name like Agro-smart Package.

\section{c. Profiles of the participants before and after joining in organic agroedu-tourism}

Participants' satisfaction joining organic agroedu-tourism could be seen through cognitive, preferences, expectations and appreciation perspective (Figure 3). Analysis of participant satisfaction joining organic agroedu-tourism aims to represent the needs of visitors so that members of farmer groups could develop a better business.

Before joining to the organic agroedu-tourism, most participants did not know the benefit of manure for agriculture. Improved cognitive competence of participants occurs after joining the organic agroedu-tourism (Figure 3a). An improved understanding of the participants shows that the organic agroedu-tourism deserves to be media learning for students who want to learn about organic farming.

Participants have similar preference to join organic agroedu-tourism, both before and after the activity (Figure 3b). The same preference of participants shows that the organic agroedutourism can fulfill the participant's understanding that was high at the beginning of the activity. Meanwhile, the high preference of participants at the end of activity means that participants have a desire to revisit and to join related activities in the future.

Participants have less ability to process manure and gardening before joining agroedu-tourism. 
However, the knowledge and skills of participants inclined after joining the organic agroedu-tourism (Figure 3c). Based on this, it can be seen that the organic agroedu-tourism can increase participant satisfaction by fulfilling their expectations in terms of improving the experience and skills of farming and gardening.

Appreciation aspects of participants show the related data distribution, both before and after joining organic agroedutourism (Figure 3d). Almost all participants have a high appreciation to recommend others to join organic agroedu- tourism. The high appreciation of participants in the beginning may be because the participants know the benefits of breeding and gardening through living environment, lessons in school and information in mass media. Meanwhile, the high appreciation of the participants at the end of the activity may be due to an initial understanding of participants and additional information as well as the knowledge of organic agro system. The participants have willingness to recommend others to join organic agroedu-tourism because they hope that the others will get the same experience.
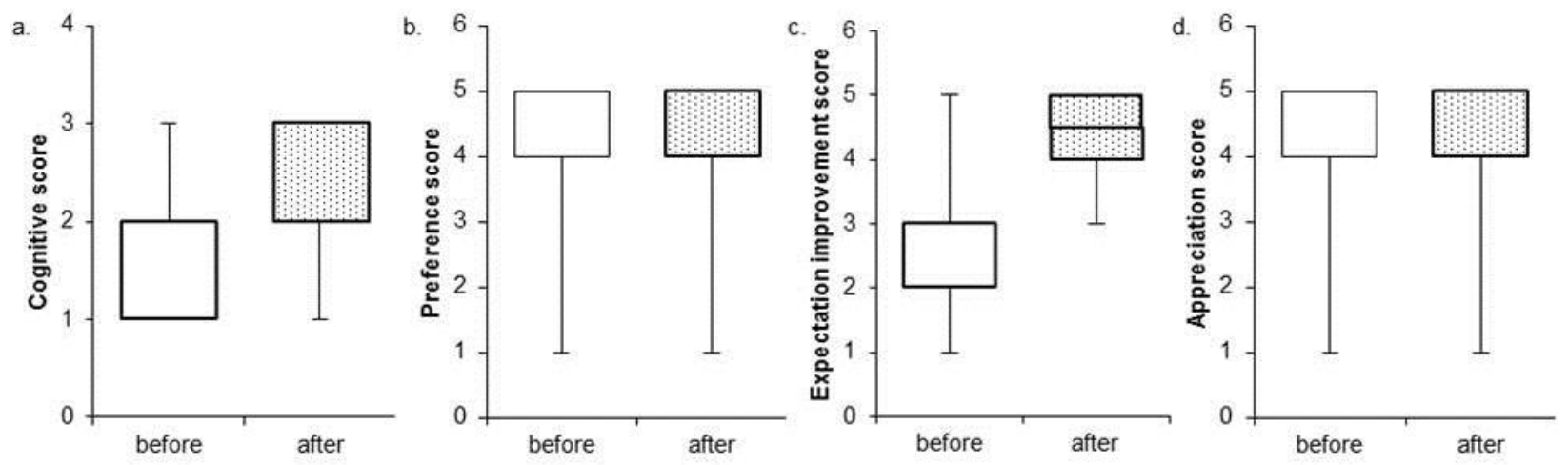

Figure 3. Improvement of participants' experience and satisfaction after joining organic agroedu-tourism. a. Cognitive score: 1) No information, 2) well information but no experience and 3) well information and experience; b. Preference score: 1) No interest, 2) less interest, 3) indifferent, 4) interest and 5) very interest; c. Expectation score: 1) No experience and skills, 2) less experience and skills improvement, 3) unversed, 4) more experience and skills improvement and 5) many experience and skills improvement; d) Appreciation score: 1) No appreciation, 2) less appreciation, 3) unsure, 4) appreciated and 5) high appreciation.

\section{d. Cognitive, preference, expectation and appreciation of participants}

Changes in cognitive aspects of the participants about the benefits of manure management on farms vary in each school (Figure 4a). Students from city and village 2 have lower initial understanding than the other schools. The low level of initial understanding students in these schools could be influenced by parent's occupation and location of house and school that is far away from farm area, so that information about the utilization of manure is rarely obtained. Nevertheless, they have the highest increase in understanding. This information shows that the organic agroedu-tourism can increase the participant understanding about integrated organic farming. Participants from village 3 have the best-initial understanding (Figure 4a). It could cause by parent's occupation background of $50 \%$ participants were a farmer who have livestock and vegetable cultivation at home. Therefore, participants have gained information about the benefits of manure that they received from their parents and environment around them. The difference of students' understanding who join the agroedu-tourism could be affected by several factors, such as interest and motivation of the participants [20], environment and learning material [21], experience and attention of students to agroedu-tourism [13].

Almost all participants are interested in joining organic agroedu-tourism that is shown by data distribution on 4-5 (Figure 4b). Participants have high initial interest to join organic agroedutourism. The condition can be because the participants feel curious about the activities on offer as well as the excellent promotion of 
teachers and facilitators. Information gathered from brochures and testimony plays an important role in promoting tour packages [22]. The interests of the participants to join the organic agroedu-tourism are unchanging even though the participants have followed organic agroedutourism. The result suggests that the organic agroedu-tourism be able to maintain high initial perceptions of participants about the activities and may participants re-visit to join a similar activity. Participants from village 2 were changing their interested after joining the organic agroedu-
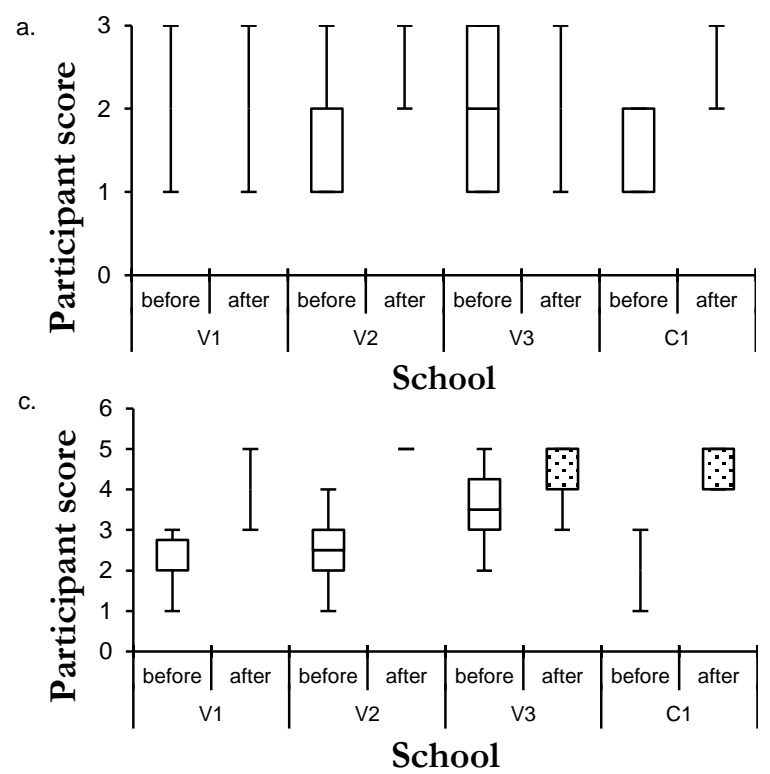

tourism. The decrease in the interest may be because the participants had a high expectation at the beginning of activity, but the activity is not as good as imagined. Another research showed that the customer will be satisfied when the offered product meets their needs and desires [23]. The decreased interest of village two students is needed to be re-analyzed by farmer group in order to create better-innovative tourist attraction to meet the satisfaction of all participants.
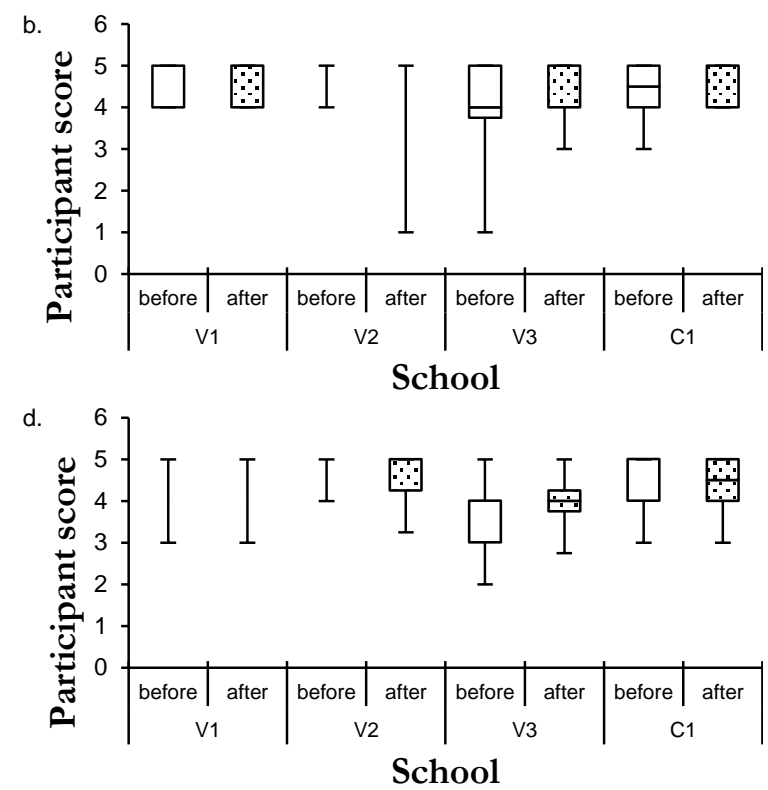

Figure 4. Satisfaction variations among schools participated in joining organic agroedu-tourism. a) Cognitive, b) preference, c) expectation improvement and d) appreciation aspect. V1, V2, V3 = students respectively from village 1 to 3 and $\mathrm{C} 1=$ students from city.

Changes of participants' expectations varied after joining the organic agroedu-tourism (Figure 4c). Participants from city, village 1 and 2 have less initial knowledge and skills in agriculture field. However, after joining the organic agroedutourism, their experience and skills increased. This increase indicates that the organic agroedutourism can fulfill the expectations of participants. Participants from village 3 have the highest initial experience and skills. The high initial experience and skills of these students could be because they sometimes help their parents in taking care of livestock and vegetable. Nevertheless, organic agroedu-tourism still provides new skills and experience for the participants. The condition proves that the materials offered by the guide were able to increase the experience and skills of participants from various family backgrounds. The fulfillment of the expectations of participants to develop experience and skills also indicate participant's satisfaction about the products and services that given by farmers group. Some researchers reported that visitors' expectations influenced significantly their satisfaction $[24,25,26]$. In Antalya Turkey, tourists who came with high expectations would back home with high satisfaction [25]. However, visitors' satisfaction is various in all aspects presented. The phenomenone indicates that everything shown in the tourism attraction is a source of satisfaction and fulfillment of visitors' needs. This condition 
makes the organizer always develop creative and innovative products and services.

The appreciation of participants to recommend others to join organic agroedutourism is nearly similar, both before and after the activity (Figure 4d). The initial participants' appreciation is high, except participants from village 3. The low initial appreciation of this students could cause by the activities that offered are assumedly the same as the usual activities at home. Therefore, they thought that the organic agroedu-tourism was less interesting to be offered to others. However, the appreciation of all participants increased after joining the organic agroedu-tourism. It was may be because the participants received the benefits from the activities, impressed with the experience, and they have the intention to promote these agricultural activities. A willingness to share the same experience is also a factor of their high appreciation to invite others to join similar events. Based on those results, it is found that factors affecting the participants' appreciation are family background, community, understanding and experience of each individual. Research on children's eating pattern shows that family and environment affect children's appreciation to certain foods, such as fruit, vegetables [27] and seafood [28]. The data suggests that the family characteristics influence children's behavior and appreciation.

\section{e. Strategies of organic agroedu-tourism development}

From the experiment results, it reveals that the organic agroedu-tourism can develop understanding, knowledge and skills of the participants in integrated organic farm. It is also possible to be revisited and promoted by the participants. However, organic agroedu-tourism also has weaknesses, such as not all participants are interested in all packages provided.

Karya Makmur 1 Farmer Group has implemented some strategies to solve the weaknesses and to improve the organic agroedutourism qualities. The strategies are are: 1) Improving the facilities and attractions for all participants from various backgrounds, for example, selecting an attractive name for the package, adding an exciting educational games and adding a package tour according to the age category of visitors; 2) Identifying visitors' capacity to the effectiveness of the program; 3) Enhancing farmer group members' skills as tour guides by doing training and comparative studies to other groups with similar activity; 4) Making an action of organic agroedu-tourism relevant with school curricula, such as natural science and environmental education; and 5) Promoting it to public.

\section{CONCLUSIONS}

Participants have enthusiasm to join organic agroedu-tourism and the most-exciting package is the Organic Garden Tour. Organic agroedutourism could enhance the participants' knowledge, experience and skills on integrated organic farming, but not all participants are interested in joining all packages. The farmer groups need to manage strategies to improve the quality of organic agroedu-tourism, such as improving facilities and attraction tourism, identifying visitors' capacity, enhancing farmer group skills as tour guide, making the activity of relevant with the school curriculum and doing promotion to public.

\section{ACKNOWLEDGMENT}

Author would like to express sincere gratitude to Ratih Nila Pamungkas, Bernadeta P., Zidny Furoidah, and Hamdani from Biology Department, the University of Brawijaya; member of Karya Makmur 1 group for supporting this study.

\section{REFERENCES}

1. Department of Agriculture (2005) Revitalisasi Pertanian, Perikanan dan Kehutanan. www.deptan.go.id. Accessed on 18 March 2013.

2. Department of Agriculture (2012) Program Kawasan Rumah Pangan Lestari. Info Litbangtan VII (6): 1.

3. Clayton S (2007) Domesticated Nature: Motivations for Gardening and Perceptions of Environmental Impact. Journal of Environmental Psychology. 27: 215-224.

4. Nilson R (2012) The Potential of Home Gardening as a Mode of Environmental Education: Connections to Environmental Problem Solving. School of The Environment. Washington State University.

5. Gibbs D (2007) The Role of Ecopreneurs in Developing a Sustainable Economy. Corporate Responsibility Research Conference: 1. 
6. McEwen T (2012) What, Whay, and How of Ecopreneurship: Implication for Entrepreneurship Education. Proceedings of Allied Academies International Conference. 18(2): 3340.

7. Talwar V (2013) Ecopreneurs: The New Trend For Entrepreneurs. International Journal of Research in Finance \& Marketing. 3(2): 52-62.

8. Lasner T, Hamm U (2012) Ecopreneurship in Aquaculture-The Adaption of Organic Fishfarming Methods. Proceedings of the Third Scientific Conference of ISOFAR. 2: 72-75.

9. Saparyati DI (2008) Kajian Peran Pendidikan Terhadap Pembangunan Pertanian di Kabupaten Demak. Tesis Program Pascasarjana, Teknik Pembangunan Wilayah dan Kota, Universitas Diponegoro. Semarang.

10. Census of Agriculture. 2013. Jumlah Rumah Tangga Pertanian. www. st2013. bps. go. id. Accessed on 18 November 2013.

11. Soil Association (2013) Organic Market Report 2013. www. soilassociation. org / marketreport. Accessed on 17 November 2013.

12. Willer H, Lernoud J (2013) Current Statistics on Organic Agriculture Worldwide: Organic Area, Producers and Market. In: FiBL \& IFOAM (2013): The World of Organic Agriculture. Statistics and Emerging Trends. Frick \& Bonn.

13. Fauziah HN, Arisoesilaningsih E, Yanuwiadi B (2013) Affectivity of Agroedutourism to Strengthen Healthy Agro-Ecosystem Awareness of Students in Some Elementary Schools in Malang Raya, East Java. Journal of Indonesian Tourism and Development Studies 1 (1): 1-5.

14. Amini R, Munandar A (2010) Pengaruh Model Pembelajaran Pendidikan Lingkungan Berbasis Outdoor Terhadap Penguasaan Konsep Pendidikan Lingkungan Bagi Calon Guru Sekolah Dasar. Jurnal Penelitian Pendidikan. 11(1): 14-21.

15. D'Amato LG, Krasny ME (2011) Outdoor Adventure Education: Applying Transformative Learning Theory to Understanding Instrumental Learning and Personal Growth in Environmental Education. The Journal of Environmental Education. 42(4): 237-254.

16. Rocmah LI (2012) Model Pembelajaran Outbond untuk Anak Usia Dini. Pedagogia. 1(2): 173-188.

17. Astutik S (2012) Meningkatkan Hasil Belajar Siswa dengan Model Siklus Belajar (Learning Cycle 5E) Berbasis Eksperimen Pada Pembelajaran Sains di SDN Patrang 1 Jember. Jurnal Ilmu Pendidikan Sekolah Dasar. 1(2): 143-153.
18. Sudarmiatin (2009) Model Perilaku Konsumen dalam Perspektif Teori dan Empiris pada Jasa Pariwisata. Jurnal Ekonomi Bisnis. 14(1): 1-11.

19. Nasution, SM, Nasution A, Damanik J (2005) Persepsi Wisatawan Mancanegara terhadap Kualitas Objek dan Daya Tarik Wisata (ODTW) Sumatera Utara. Jurnal Studi Pembangunan. 1(1): 81-96.

20. Aritonang KA (2008) Minat dan Motivasi dalam Meningkatkan Hasil Belajar Siswa. Jurnal Pendidikan Penabur. 7(10): 11-21.

21. Carbone A, Mitchell I, Gunstone D, Hurst J (2009) An Exploration of Internal Factors Influencing Student Learning of Programming. Conference in Research and Practice in Information Technology. 95: 1-10.

22. Molina AM, Gomez, Martin-Consuegra D (2010) Tourism Marketing Information and Destination Image Management. African Journal of Business Management. 4(5): 722-728.

23. Hanif M, Hafeez S, Riaz A (2010) Factors Affecting Custumer Satisfactions. International Research Journal of Finance and Economics. 60: 44-52.

24. Aggarwal VS, Handa M, Singh AK (2010) Mapping Expectation and Satisfaction Level of Adventure Tourist for Land, Air and Water Base Sports in India. DIAS Technology Review. 1(2): 9-19.

25. Aksu A, Icigen ET, Ehtiyar R (2010) A Comparison of Tourist Expectations and Satisfaction: A Case Study from Antalya Region of Turkey. Turizam. 14(2): 66-77.

26. 26. Rahma T, Halim LV, Hariyato SVH (2012) Hubungan Antara Kualitas Layanan dan Harga dengan Kepuasan Konsumen Online Shooping pada Mahasiswi Universitas Surabaya. Jurnal Ilmiah Mahasiswa Universitas Surabaya. 1(1): 212.

27. Lowe CF, Horne PJ, Tapper K, Bowdery M, Egerton C (2004) Effects of a Peer Modelling and Rewards-Based Intervention to Increase Fruits and Vegetable Consumtion in Children. European Journal of Clinical Nutrition. 58: 510-522.

28. Waysima, Sumarwan U, Khomsan A, Zakaria R (2010) Sikap Afektif Ibu terhadap Ikan Laut Nyata Meningkatkan Apresiasi Anak Mengkonsumsi Ikan Laut. Journal of Nutrition and Food. 5(3): 197-204. 